\title{
Mixed Agonist/Antagonist
}

National Cancer Institute

\section{Source}

National Cancer Institute. Mixed Agonist/Antagonist. NCI Thesaurus. Code C154902.

A class of substances that binds to and acts as a full agonist or partial agonist at one receptor and an antagonist at another. 